\title{
Seed priming with seaweed extract mitigate heat stress in spinach: effect on germination, seedling growth and antioxidant capacity
}

Antônio Pereira dos Anjos Neto1,* (iD), Gustavo Roberto Fonseca Oliveira² (iD), Simone da Costa Mello ${ }^{3}$ (iD), Marcio Souza da Silva ${ }^{4}$ (D), Francisco Guilhien Gomes-Junior ${ }^{3}$ (D), Ana Dionisia da Luz Coelho Novembre ${ }^{3}$ (D), Ricardo Antunes Azevedo 5 (D)

1. Universidade Federal da Paraíba - Centro de Ciências Agrárias - Programa de Pós-Graduação em Agronomia - Areia (PB), Brazil.

2. Universidade Estadual Paulista “Júlio de Mesquita Filho” - Faculdade de Ciências Agronômicas - Departamento de Produção Vegetal - Botucatu (SP), Brazil.

3. Universidade de São Paulo - Escola Superior de Agricultura “Luiz de Queiroz” - Departamento de Produção Vegetal Piracicaba (SP), Brazil.

4. Universidade Estadual Paulista “Júlio de Mesquita Filho” - Faculdade de Ciências Agrárias e Veterinárias Departamento de Produção Vegetal - Jaboticabal (SP), Brazil.

5. Universidade de São Paulo - Escola Superior de Agricultura “Luiz de Queiroz” - Departamento de Genética - Piracicaba (SP), Brazil.

\begin{abstract}
Spinach seeds are sensitive to high temperatures during germination and plant growth. It is known that seed priming with water or with seaweed extract (SWE) may enhance germination and seedling growth. The objective of this study was to evaluate the effects of seed priming with SWE (Ascophyllum nodosum) on the germination, seedling growth and antioxidant capacity of spinach seedlings under conditions of heat stress. Five concentrations of $\operatorname{SWE}(0.0,0.15,0.30,0.60$ and $1.2 \%$ ) were used for priming the seeds under two temperatures $\left(15\right.$ and $30^{\circ} \mathrm{C}$ ). Seeds primed with $0.3 \%$ SWE had the greatest activity of antioxidant metabolism and showed improved germination percentage, germination speed and seedling vigor under conditions of heat stress $\left(30^{\circ} \mathrm{C}\right)$ compared to nonprimed controls. Hydropriming and priming with $0.3 \%$ SWE resulted in lower contents of hydrogen peroxide $\left(\mathrm{H}_{2} \mathrm{O}_{2}\right)$ and malondialdehyde (MDA) under heat stress than control (nonprimed spinach seeds). This study showed that seed priming with SWE was effective to mitigate stress due to high temperatures and to improve spinach seed germination and seedling vigor.
\end{abstract}

Key words: Spinacea oleracea, Ascophyllum nodosum, seed-primed, thermal stress.
Received:

Mar. 29, 2020

Accepted:

Sep. 1, 2020

Section Editor:

Hector Valenzuela

${ }^{\star}$ Corresponding author: ap.anjosneto@gmail.com

\section{INTRODUCTION}

Spinach (Spinacea oleracea) is cultivated mainly during the cool season, with optimal ranges for germination and plant growth between 7 to $24^{\circ} \mathrm{C}$ and 15 to $20^{\circ} \mathrm{C}$, respectively (Chitwood et al. 2016). High temperatures are common in tropical and subtropical climates and may delay seed germination or loss of vigor that lead to reduced emergence and seedling establishment (Wahid et al. 2007). However, the adverse effects of heat stress can be ameliorated by priming techniques.

Seed priming is a process in which seeds are hydrated in different solutions including natural or synthetic compounds as priming agents (Jisha et al. 2013). This technique stimulates pregermination metabolic processes, increases the antioxidant system activity and the repair of membranes (Masondo et al. 2018) under abiotic stress. Under conditions of heat stress, seed priming was effective on melon (Lira et al. 2015), onion (Murili et al. 2016), pepper (Alqui et al. 2014), spinach (Ziaf et al. 2017) and other crops.

Several priming approaches that include hydropriming and chemical priming are being used. Hydropriming consists of noncontrolled water uptake, while chemical priming is associated with controlled water absorption by using osmotic 
solutions (Nascimento 2004). Hydropriming is a simple technique of low cost that may be efficient to enhance the germination percentage and early seedling growth in vegetables grown under stressful conditions (Yan 2016). For chemical priming, salts, phytohormones and biostimulants may be used as chemical agents. Among biostimulants, seaweed extract (SWE) with Ascophyllum nodosum has been used to enhance seed germination (El-Sheekh and El-Saied 2000), promote growth and increase the yield and quality of vegetable crops (Sarhan et al. 2011; Hernández-Herrera et al. 2014).

Seaweed extracts are biodegradable, nontoxic, nonpolluting and nonhazardous organic biostimulants to humans, animals and the environment (Craigie 2011). Commercial SWEs have a complex composition, consisting of nutrients, amino acids, oligosaccharides and plant hormones (Sharma et al. 2012). Seaweed extracts enhance the antioxidant system activity that scavenge the reactive oxidative species (ROS) induced by stresses and physiological process during germination (Bailly 2004).

The ROS accumulate in the plant cells under conditions of environmental stress and are inactivated by antioxidant enzymes in the reduced state and by biological antioxidants that are small organic compounds or peptides (Taiz et al. 2017). In plants, ROS consist of the main metabolites of signaling and regulation, coordinating defense, growth and cell death (Carmody et al. 2016). Thermal stress can denature proteins, disrupt the integrity of the membrane system and the proper functioning of metabolic processes in cells, resulting in the production of large amounts of ROS and severe oxidative stress (Bita and Gerats 2013). Seed priming is able to provide tolerance to abiotic stress by activating DNA and antioxidant repair mechanisms, favoring seedling germination and growth (Woityla et al. 2016). Although the beneficial effects of SWE include improved seed germination of vegetables such as lettuce (Möller and Smith 1998) and faba bean (El-Sheekh and El-Saied 2000), no report was found about the response of spinach seed germination to priming with SWE under heat stress.

Thus, the objective of this study was to determine the effects of seed priming with (SWE) on germination, seedling growth and antioxidant capacity of spinach under heat stress.

\section{MATERIAL AND METHODS}

\section{Plant material and treatments}

Seeds of spinach (Spinacia oleracea) cultivar Python (Rijk Zwaan BR), resistant to cucumber mosaic virus (CMV)/Pfs $1-7,9,11,13,15,16$ was used for this study. The seeds were soaked in solutions of SWE (A. nodosum) at concentrations of 0.0, $0.15,0.30,0.60$ and $1.20 \%$ from the commercial product Improver (composed of $2 \%$ molybdenum and $96.13 \%$ Ascophyllum nodosum), at a rate of $10 \mathrm{ml}$ of the solution per gram of seed. In addition, seeds soaked with water and seeds without priming were included as controls. After priming for $6 \mathrm{~h}$ at $15^{\circ} \mathrm{C}$ in the dark, the primed seeds were washed three times with distilled water for $2 \mathrm{~min}$ each and surface-dried on absorbent paper and dehydrated at $30^{\circ} \mathrm{C}$ until reaching $10 \%$ moisture prior to priming. The imbibition time and drying time of the seeds were determined in preliminary tests (Fig. 1).

\section{Germination test}

The primed and nonprimed seeds were placed in light transparent plastic boxes $(11 \times 11 \times 3.5 \mathrm{~cm})$ containing two sheets of blotting paper moistened with $14 \mathrm{ml}$ of water and kept at $15{ }^{\circ} \mathrm{C}$ (ideal temperature) or $30^{\circ} \mathrm{C}$ (heat stress) and a light $(6 \mathrm{~h}) /$ dark $(18 \mathrm{~h})$ photoperiod. Each treatment was replicated four times with 50 seeds per replicate. The germination rates were counted at seven, 14 and 21 days after sowing, according to the rules for seed testing (Brazil 2009).

\section{Germination rate index}

The germination rate index of spinach seeds was determined based on the increase on the number of new seedlings counted daily throughout the test period. The following the formula was used (Maguire 1962): IVG $=(\mathrm{N} 1 / \mathrm{D} 1)+\ldots+$ (Nn / Dn); where $\mathrm{Nn}$ = number of normal seedlings counted daily; $\mathrm{Dn}$ = days after test installation (Nakagawa 1994). 

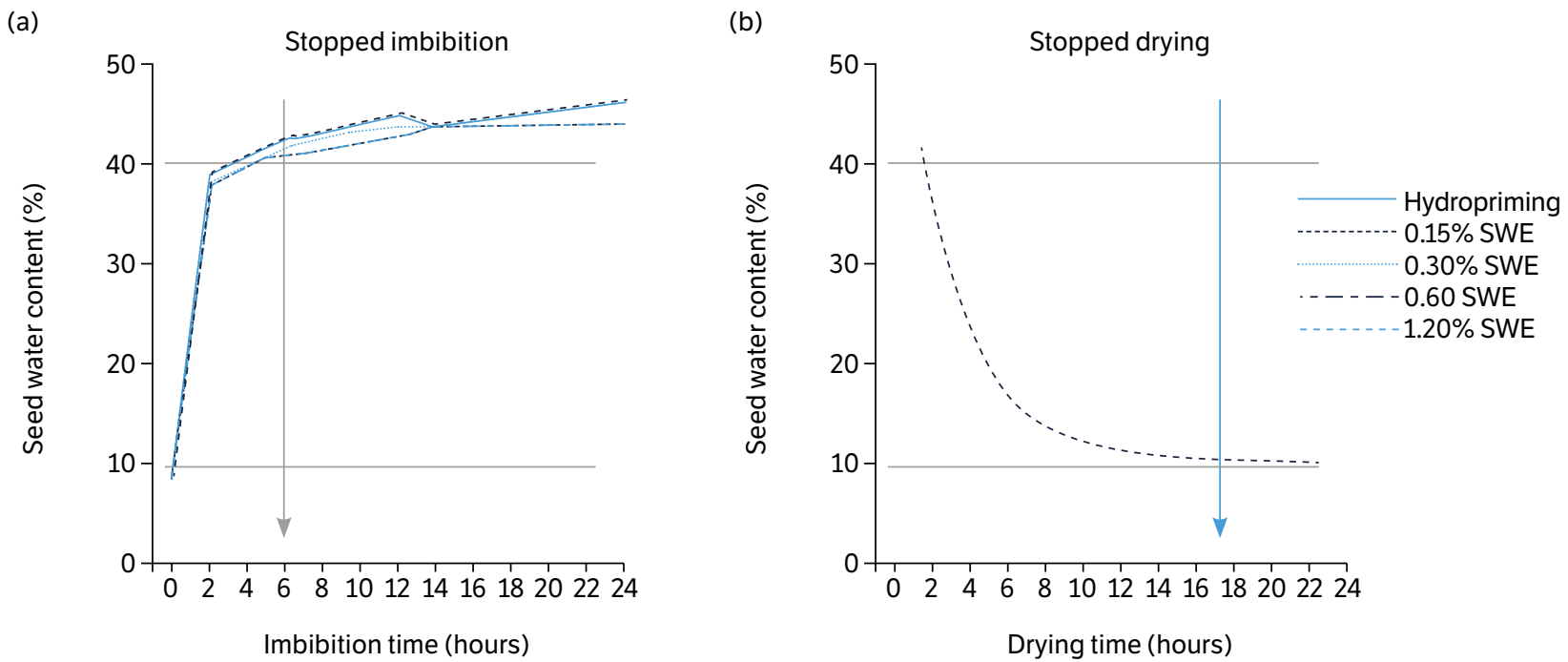

Figure 1. a) Imbibition time $\left(15^{\circ} \mathrm{C}\right)$ and b) Drying time $\left(30^{\circ} \mathrm{C}\right)$ of seed priming test on spinach.

\section{Germination speed}

The germination speed test was also carried out in parallel to the germination test with four replications of 50 seeds of each treatment. The evaluations were carried out every $24 \mathrm{~h}$ for 14 days, and the number of normal seedlings was computed. The time required for germination of $50 \%$ of the seeds was calculated through the analysis of accumulated germination data using the curve adjustment module of the Germinator software (Joosen et al. 2010) and the results were expressed in days.

\section{Seedling growth analysis}

Four replicates of 25 seeds each, were rolled in a germitest paper, moistened with deionized water in a quantity equivalent to 2.5 times the dry weight of the paper and kept in a germinating chamber with a temperature set at 15 and $30{ }^{\circ} \mathrm{C}$ in the dark for four days. Then, the seedlings were transferred to a blue rubberized polymer sheet and the images were obtained through an HP Scanjet 200 scanner, installed inverted inside a $60 \times 50 \times 12 \mathrm{~cm}$ aluminum box, adjusted to a resolution of 300 dpi coupled to an Intel Core i7 computer $(3.50 \mathrm{GHz}, 16 \mathrm{~GB}$ RAM and $1 \mathrm{~TB}$ HD). The images were analyzed with the Seed Vigor Imaging System (SVIS) software and seedling lengths were calculated as described by Sako et al. (2001).

\section{Biochemical analysis}

Primed seeds were collected $24 \mathrm{~h}$ after sowing, frozen in liquid nitrogen and stored at $-80{ }^{\circ} \mathrm{C}$ for biochemical analysis. Lipid peroxidation was determined by measuring the content of malondialdehyde (MDA), which was extracted with $0.25 \%$ thiobarbituric acid (TBA) in the absorbance at 532 and $600 \mathrm{~nm}$ (Heath and Packer 1968); The $\mathrm{H}_{2} \mathrm{O}_{2}$ content was determined according to the methodology described by Alexieva et al. (2001). Seed material samples (0.1 g) were macerated in $0.1 \%$ ( $\mathrm{m} / \mathrm{v})$ of trichloroacetic acid and centrifuged at $10,000 \mathrm{rpm}$ for $10 \mathrm{~min}$ at $4{ }^{\circ} \mathrm{C}$. The supernatant $(1 \mathrm{ml})$ was mixed with $1 \mathrm{~mL}$ of $100 \mathrm{mmol} \cdot \mathrm{L}^{-1}$ potassium phosphate buffer ( $\mathrm{pH}$ 7.5). The absorbance was read at $390 \mathrm{~nm}$ and the results expressed at mmol/g of fresh matter.

\section{Statistical analysis}

In all sets of data obtained, data normality was analyzed using the Shapiro-Wilk test. The data were submitted to analysis of variance by the $\mathrm{F}$ test. The experiment was carried out in a completely randomized design with two temperatures ( 15 and $30{ }^{\circ} \mathrm{C}$ ) as factors, a control (seeds not subjected to priming) and four treatments with priming (hydropriming, $0.15,0.30$, 
0.60 and $1.20 \%$ of seaweed extract $)$ with four replications $(n=48)$. The effects of the treatments were analyzed separately in the conditions without stress $\left(15^{\circ} \mathrm{C}\right)$ and with thermal stress and $\left(30^{\circ} \mathrm{C}\right)$. The mean separation of treatments was evaluated by the Tukey's test at $\mathrm{p}<0.05$ using the statistical software R (R Core Team 2020).

\section{RESULTS AND DISCUSSION}

This study evaluated the effect of controlled hydration (priming) as a promoter of rapid germination and seedling growth. The study evaluated the use of a biostimulant based on algae extract (SWE), which increased seed vigor under thermal stress ( 15 and $30^{\circ} \mathrm{C}$, respectively). In addition, priming with SWE provided a greater antioxidant effect compared to hydropriming (water), mitigating possible cellular damage caused by reactive oxygen species (ROS) due to the high temperature.

Total germination (G), first count germination (FG), germination speed index (GRI) and seedling length (SL) of spinach under optimal temperature $\left(15^{\circ} \mathrm{C}\right)$ and heat stress $\left(30^{\circ} \mathrm{C}\right)$ are shown in the Figs. 2 and 3, respectively. For nonprimed seeds, the $\mathrm{G}$ was 89 and $55 \%$ at 15 and $30^{\circ} \mathrm{C}$, respectively. The spinach primed seeds with water or SWE at optimal temperature had higher germination rates compared to the nonprimed seeds, except to the $1.20 \%$ SWE treatment, which reduced the germination. Under heat stress, however, priming with $0.30 \%$ SWE and hydropriming had the greatest germination rates compared to the control, increasing by 25 and 16\%, respectively (Figs. 2a and 3a).

Under optimal temperature, GRI improved with the seed priming treatments, except for SWE at 1.20\%, which was similar to nonprimed seeds. The highest GRI was reached with hydropriming and $0.15 \%$ SWE as compared to nonprimed seeds. For seeds germinated under heat stress, hydropriming and priming with SWE 0.30 or $0.60 \%$ showed the highest GRI as compared nonprimed seeds (Figs. $2 \mathrm{c}$ and $3 \mathrm{c}$ ). Under optimal temperature, the greatest SL was obtained with hydropriming. Under heat stress, SL increased with hydropriming and SWE at doses of $0.15,0.30$, and $0.60 \%$ (Figs. $2 \mathrm{~d}$ and $3 \mathrm{~d}$ ).

(a)

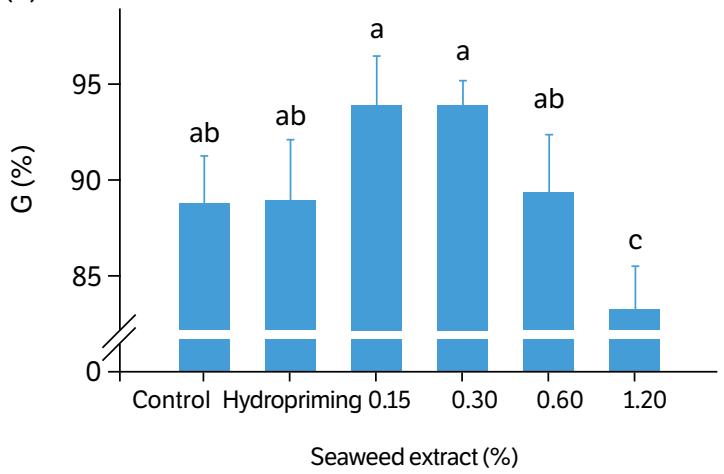

(c)

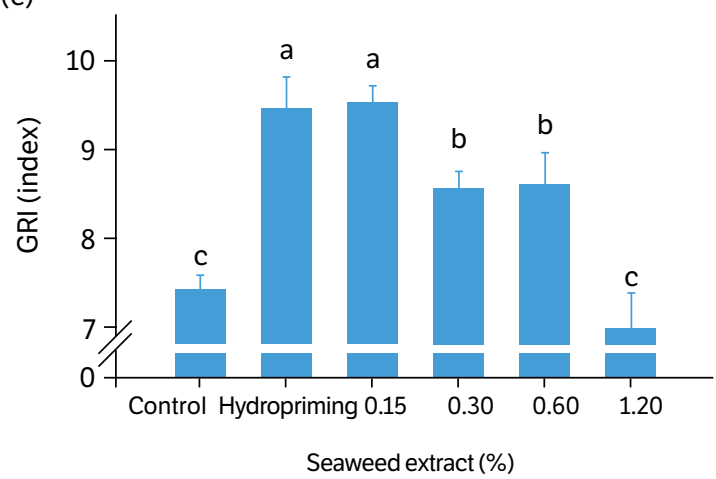

(b)

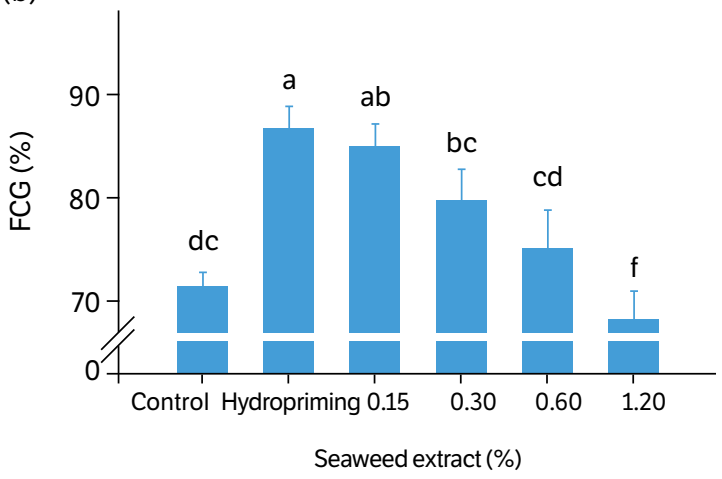

(d)

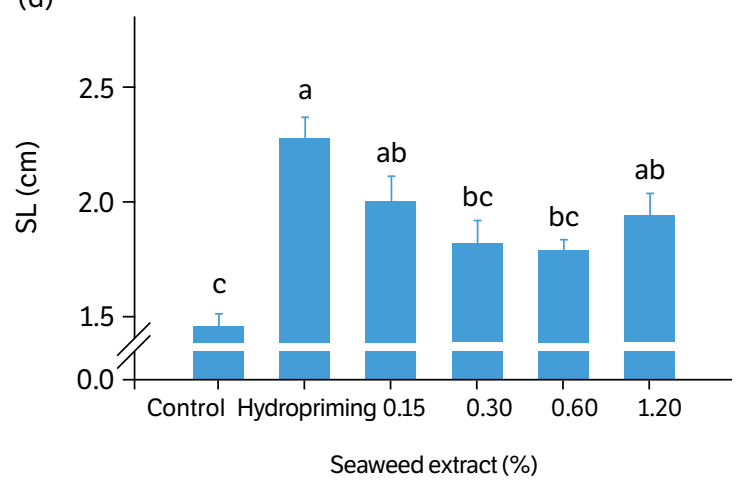

Figure 2. a) Total germination (G), b) First-count germination (FCG), c) Germination rate index (GRI) and d) Seedling length (SL) of spinach seeds after nonpriming (control), hydropriming (water) and priming with seaweed extract (SWE) (A. nodosum) at $15^{\circ} \mathrm{C}$ (optimal temperature). 
(a)

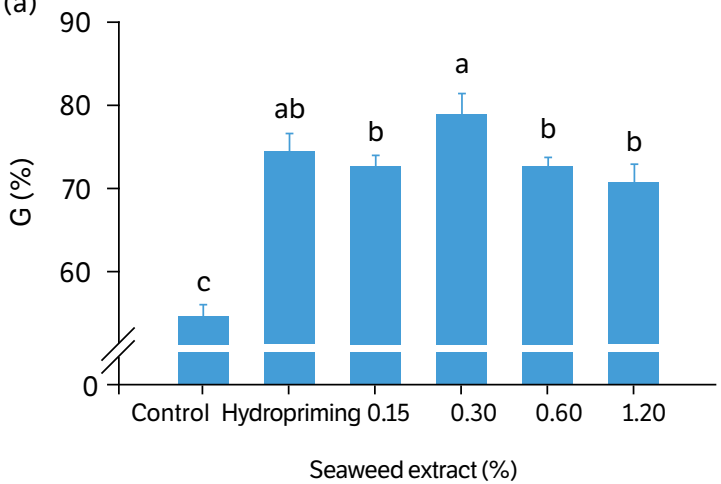

(c)

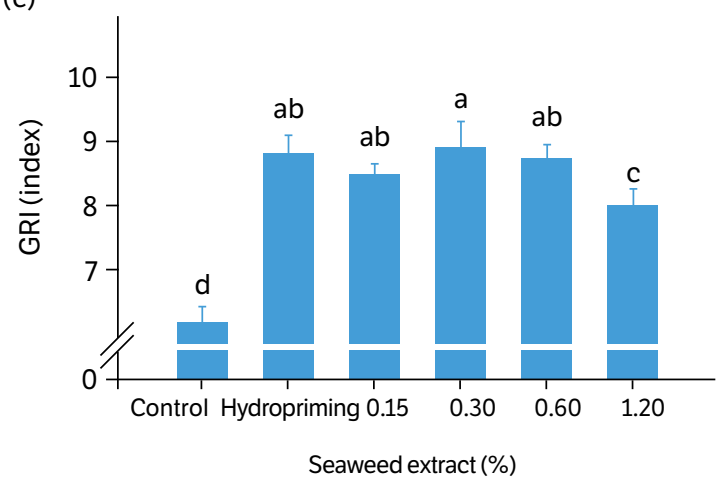

(b)

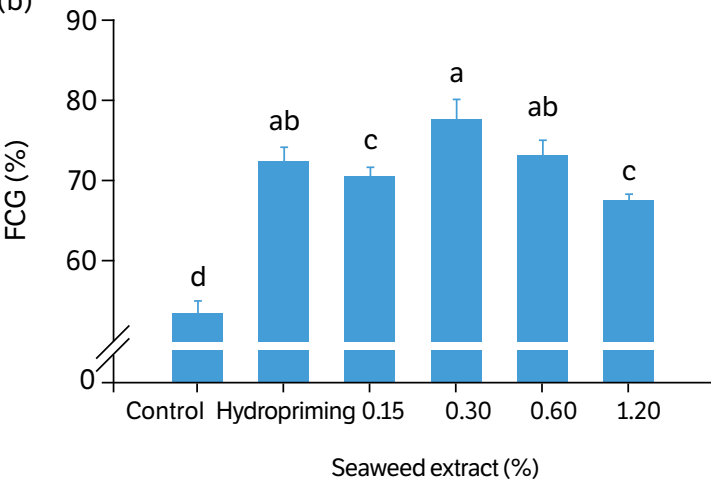

(d)

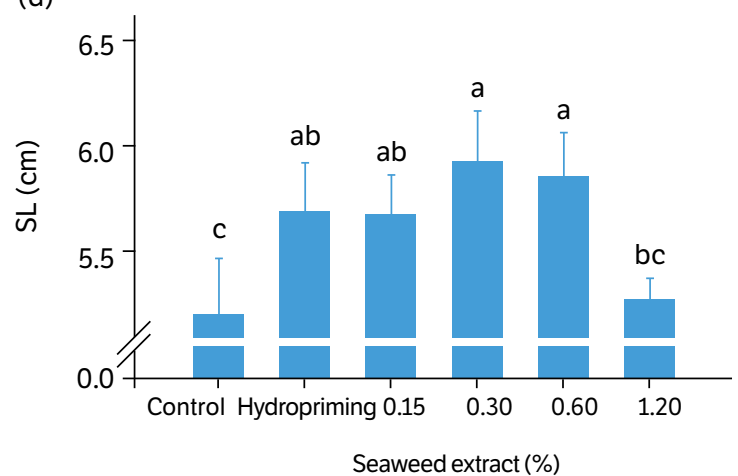

Figure 3. a) Total germination (G), b) First-count germination (FCG), c) Germination rate index (GRI) and d) Seedlings length (SL) of spinach seeds after nonpriming (control), hydropriming (water) and priming with seaweed extract (SWE) (A. nodosum) at $30{ }^{\circ} \mathrm{C}$ (heat stress).

The accumulative germination percentage over time was similar between priming-treatments and control at optimal temperature. For this condition, regardless of treatment, $50 \%$ of the seeds germinated in five days after the onset of germination (Figs. 4a and 5a). However, seeds primed with SWE and with water (hydropriming) germinated approximately in three days after the onset of germination (Figs. $4 \mathrm{~b}$ and $5 \mathrm{~b}$ ).

Under heat stress, nonprimed seed showed reduced germination and abnormal seedling growth. Therefore, elevated temperatures likely induced dormancy and affected seedling growth. Temperature is considered to be a critical environmental factor on seed germination because it inhibits radicle emergence and affects seedling growth (Ashraf and Foolad 2005). For spinach, the optimal temperature range between 15 and $20^{\circ} \mathrm{C}$ and outside of this temperature range, germination declines gradually (Chitwood et al. 2016). In this study, heat stress reduced germination of controls by 25 and 38\% at 7 and 21 days after sowing, respectively. Futhermore, heat stress delayed the germination rate index, and resulted in abnormal seedling growth (Figs. 2 and 3).

The priming techniques used did not increase the seed germination under optimal conditions, agreeing with results obtained by Möller and Smith (1998) for lettuce seed priming with SWE. Guinan et al. (2013) also found that A. nodosum extracts were less effective in plant growth under stress-free conditions. In this research, seed priming with water or SWE at 0.15 or $0.30 \%$ improved seed germination at $15^{\circ} \mathrm{C}$, possibly leading to improved seedling growth and establishment (Fig. 4). Under heat stress, osmopriming with SWE at low dosages resulted in the best germination efficiency and in improved seedling growth (Fig. 4).

The improved seedling growth observed for primed seeds with SWE $0.30 \%$ may have occurred due to the increased metabolic activity and mobilization of reserves to the embryo axis to promote fast primary root emission, as observed by Chen and Arora (2013). Guinan et al. (2013) verified the positive effects of seaweed extract as a plant growth promoter. Priming with seaweed extract (Ascophyllum nodosum) indicated that the constituents of this biostimulant include growth promoting substances (Kavipriya et al. 2011) which might help germination seeds overcome temperature stress. Masondo et al. (2018) highlighted the use of priming techniques with biostimulants as a promising alternative to enhance germination and seedling growth under abiotic stress. 

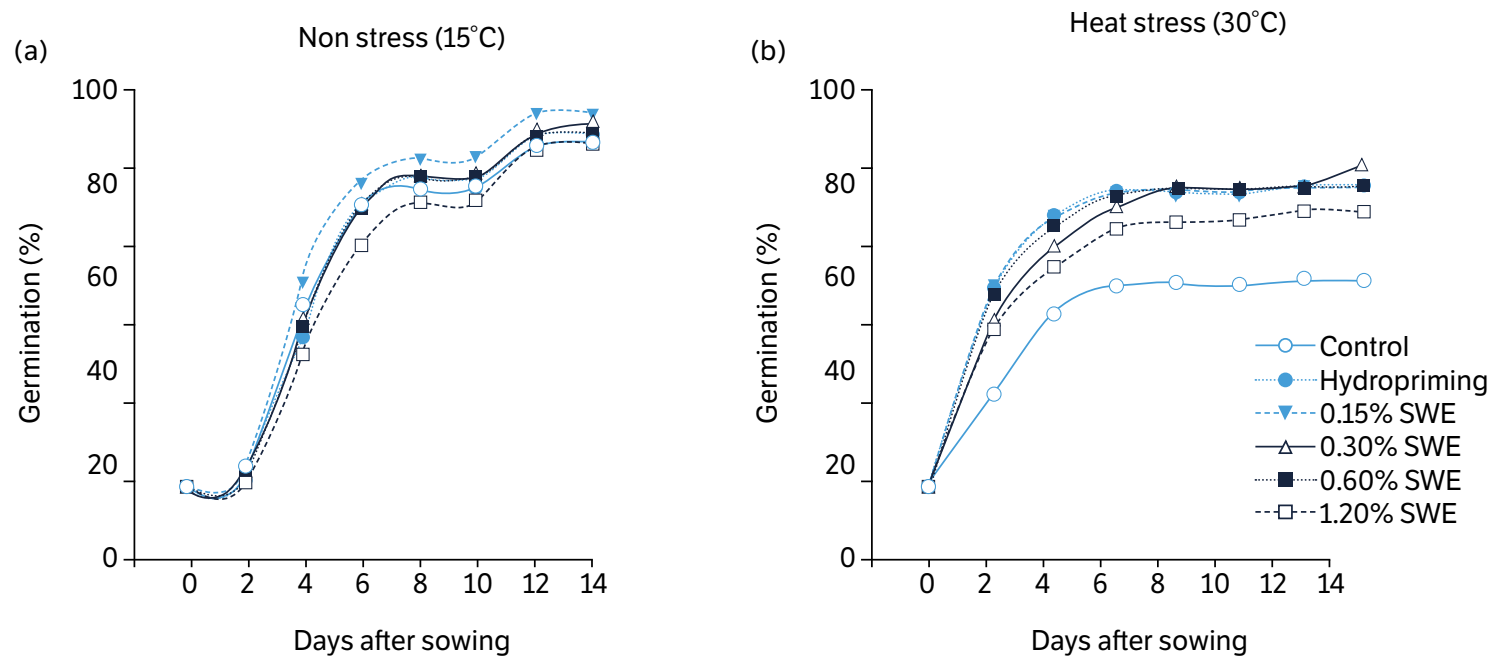

Figure 4. Acummulative germination of spinach seed priming under optimal temperature $\left(a, 15^{\circ} \mathrm{C}\right)$ and heat stress $\left(\mathrm{b}, 30^{\circ} \mathrm{C}\right)$.

(a)

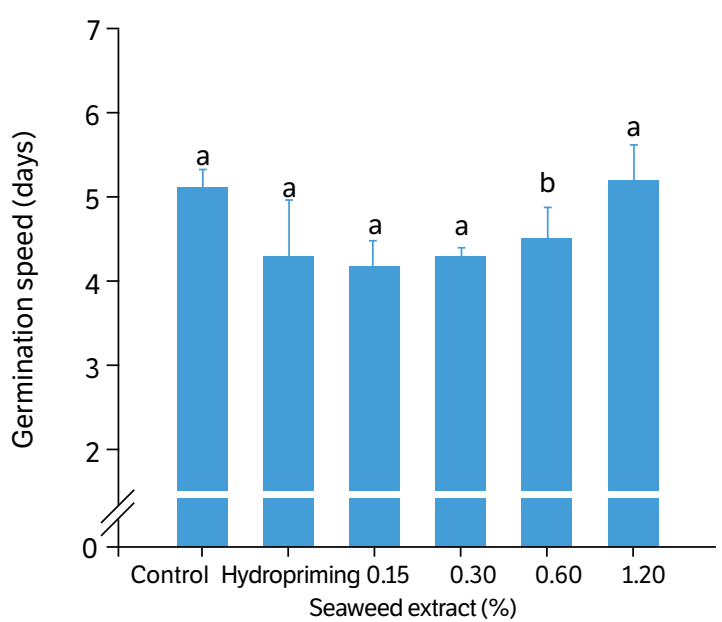

(b)

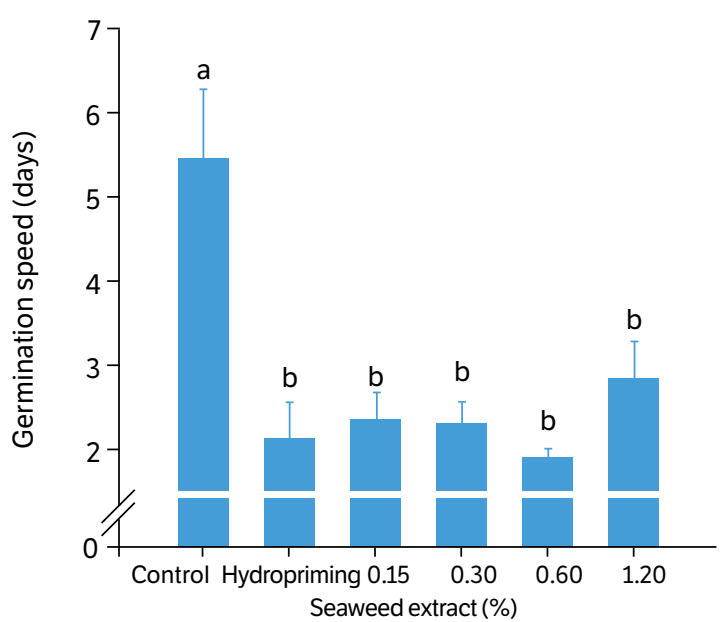

Figure 5. Germination speed of spinach seeds to form $50 \%$ of normal seedlings at optimum temperature $\left(\mathrm{a}, 15^{\circ} \mathrm{C}\right)$ and thermal stress $(\mathrm{b}$, $30^{\circ} \mathrm{C}$ ) depending on the priming treatments (hydropriming and SWE). Error bars express the standard error of the mean $(n=4)$.

The $\mathrm{H}_{2} \mathrm{O}_{2}$ and MDA content in seedlings from the seed-priming treatments with water and SWE at a rate of $0.30 \%$ optimum temperature $\left(15^{\circ} \mathrm{C}\right)$ and heat stress $\left(30^{\circ} \mathrm{C}\right)$ are shown in Figs. 6 and 7. Seeds primed with SWE $0.30 \%$ were used as a target dose to mitigate heat stress (Figs. 2,3 , and $5 \mathrm{~b}$ ). Thus, the antioxidant capacity of SWE $0.30 \%$ was evaluated to compare hydroprimed and nonprimed seeds.

Hydrogen peroxide $\left(\mathrm{H}_{2} \mathrm{O}_{2}\right)$ contents were decreased in seeds primed with SWE $(0.30 \%)$ as compared to those from nonprimed controls and to hydroprimed spinach seeds at optimal temperature. Under heat stress, primed-seeds with water and SWE $0.30 \%$ resulted in seedlings with lower hydrogen peroxide than nonprimed seeds (Fig. 6). Malondialdehyde (MDA) content in the treatment with hydropriming and $0.30 \%$ SWE decreased $(\mathrm{p}<0.05)$ as compared to controls at optimal temperature. Under heat stress, priming of seeds with SWE 0.30\% decreased MDA content in the seedlings as compared to hydropriming and nonprimed seeds (Fig. 7).

Seed priming is an important mechanism of induced resistance in plants to alleviate abiotic stress such as high temperatures that lead to increased reactive oxygen species (ROS) levels, causing redox imbalance and oxidative stress (Nahar et al. 2014). The ROS as hydrogen peroxide $\left(\mathrm{H}_{2} \mathrm{O}_{2}\right)$, superoxide $\left(\mathrm{O}_{2}^{-}\right)$, the hydroxyl radical $\left(\mathrm{OH}^{-}\right)$and singlet oxygen $\left(-\mathrm{O}_{2}\right)$ are produced naturally in cells as a signaler in plants controlling their growth and as a response of plant cells to environmental stress (Das and Roychoudhury 2014). 
(a)

Non stress $\left(15^{\circ} \mathrm{C}\right)$

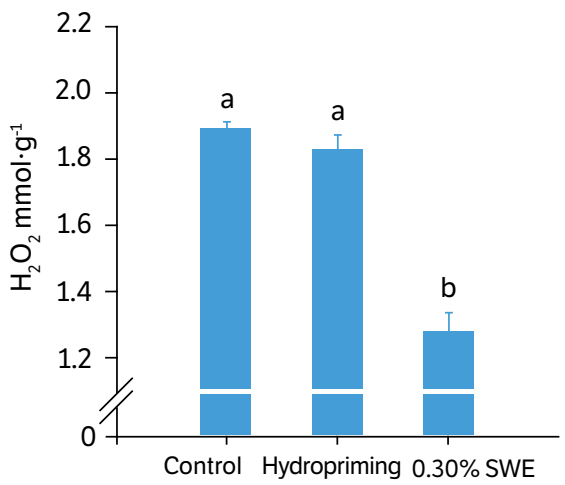

(b)

Heat stress $\left(30^{\circ} \mathrm{C}\right)$

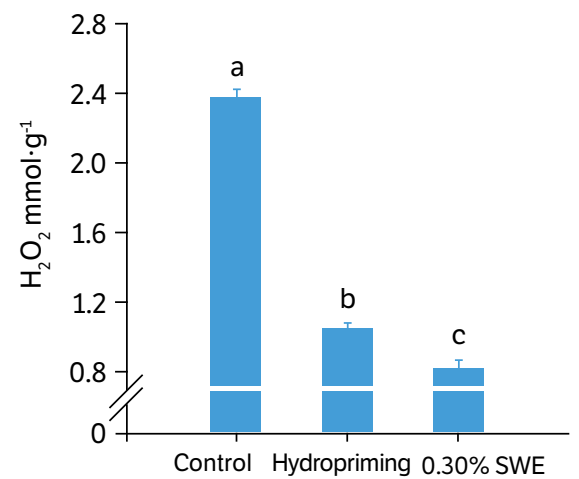

Figure 6. Hydrogen peroxide $\left(\mathrm{H}_{2} \mathrm{O}_{2}\right)$ content of seedlings obtained from treatments with seed-priming under optimal temperature $\left(a, 15^{\circ} \mathrm{C}\right)$ and heat stress $\left(\mathrm{b}, 30^{\circ} \mathrm{C}\right)$. Error bars express the standard error of the mean $(n=4)$.

(a)

Non stress $\left(15^{\circ} \mathrm{C}\right)$

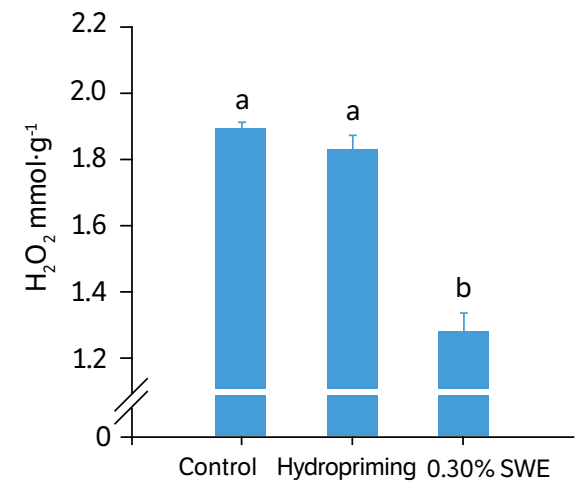

(b)

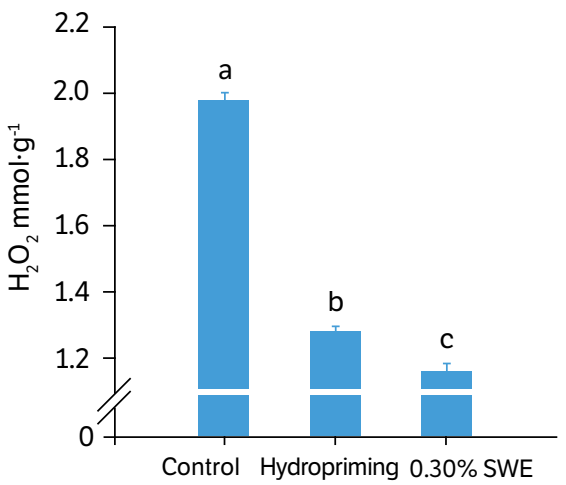

Figure 7. Malondialdehyde (MDA) content of seedlings obtained from treatments with seed-priming under optimal temperature $\left(\mathrm{a}, 15^{\circ} \mathrm{C}\right)$ and heat stress $\left(\mathrm{b}, 30^{\circ} \mathrm{C}\right)$. Error bars express the standard error of the mean $(n=4)$.

Environmental stresses, such as high temperature, cause excessive accumulation of ROS and lipid peroxidation in plants (Mittler and Zilinskas 1994; Chen et al. 2010). Thus, the treatment with $0.30 \%$ SWE plausibly reduced oxidative stress caused by hydrogen peroxide $\left(\mathrm{H}_{2} \mathrm{O}_{2}\right)$ and lipid peroxidation (MDA) during the germination process under both temperature conditions (Figs. 5 and 6). Success of the germination process, from imbibing to the primary root protrusion, depends on antioxidant protection against ROS, especially under stress conditions during the early stages of development (Bailly 2004).

Antioxidant activity is associated with germination performance (Bailly et al. 2000), and primed spinach seeds with SWE under thermal stress showed improved physiological performance than nonprimed seeds (Chen et al. 2010). Therefore, the metabolites present in the SWE possibly promoted higher efficiency in the repair mechanism of the membranes and DNA system (Chen and Arora 2013), nucleic acid synthesis, proteins, ATP production and higher efficiency of the antioxidant system (Paparella et al. 2015). Seaweed extracts with A. nodosum increased the tolerance of crops to environmental stress, such as: water stress, absorption of nutrients from the soil and antioxidant capacity of plants (Turan and Köse 2004; Verkleij 1992). The beneficial effect of $A$. nodosum is attributed to the presence of minerals, nutrients, amino acids, vitamins, pigments and complex polysaccharides that contribute to the growth of plants and antioxidant capacity (Calvo et al. 2014).

\section{CONCLUSION}

Hydropriming and a $0.30 \%$ SWE dose is an effective approach to mitigate stress due to high temperatures and enhance the germination and seedling vigor of spinach under tropical conditions. Nevertheless, more studies are needed in order 
to better understand the physiological and biochemical role of seaweed extracts during spinach seed germination and seedling growth under abiotic stress.

\section{FUNDERS}

Coordenação de Aperfeiçoamento de Pessoal de Nível Superior - Brasil

\section{AUTHOR'S CONTRIBUTION}

Conceptualization: Anjos Neto A. P., Oliveira G. R. F. and Mello S. C.; Methodology: Anjos Neto A. P., Oliveira G. R. F., Silva M. S., Azevedo R. A., Novembre A. D. L. C. and Gomes-Junior F. G.; Writing - Original Draft: Anjos Neto A. P., Oliveira G. R. F. and Silva M. S.; Writing - Review and Editing: Anjos Neto A. P., Oliveira G. R. F., Silva M. S. and Mello S. C.; Funding Acquisition: Mello S. C., Azevedo R. A. and Novembre A. D. L. C.; Resources: Mello S. C.; Supervision: Mello S. C.

\section{REFERENCES}

Alexieva, V., Sergiev, I., Mapelli, S. and Karanov, E. (2001). The effect of drought and ultraviolet radiation on growth and stress markers in pea and wheat. Plant, Cell \& Environment, 24, 1337-1344. https://doi.org/10.1046/j.1365-3040.2001.00778.x

Alqui, H., Souguir, M. and Hannachi, C. (2014). Determination of an optimal priming duration and concentration protocol for pepper seeds (Capsicum annuum L.). Acta Agriculturae Slovenica, 103, 213-221. https://doi.org/10.14720/aas.2014.103.2.6

Ashraf, M. and Foolad, M. R. (2005). Pre-sowing seed treatment a shotgun approach to improve germination, plant growth and crop yield under saline and non-saline conditions. Advances in Agronomy, 88, 223-271. https://doi.org/10.1016/S0065-2113(05)88006-X

Bailly, C., Benamar, A., Corbineau, F. and Côme, D. (2000). Antioxidant systems in sunflower (Helianthus annuus L.) seeds as affected by priming. Seed Science Research, 10, 35-42. https://doi.org/10.1017/S0960258500000040

Bailly, C. (2004). Active oxygen species and antioxidant in seed biology. Seed Science Research, 14, 93-107. https://doi.org/10.1079/ SSR2004159

Bita, C. E. and Gerats, T. (2013). Plant tolerance to high temperature in a changing environment: scientific fundamentals and production of heat stress-tolerant crops. Frontiers in Plant Science, 4, 273. https://doi.org/10.3389/fpls.2013.00273

Brazil. Ministério da Agricultura, Pecuária e Abastecimento (2009). Teste de germinação. In Regras para análise de sementes (p. 147224). Brasília: Mapa/ACS. [Accessed Feb.15, 2020]. Available at: https://www.gov.br/agricultura/pt-br/assuntos/insumos-agropecuarios/ arquivos-publicacoes-insumos/2946_regras_analise_sementes.pdf

Calvo, P., Nelson, L. and Kloepper, J. W. (2014). Agricultural uses of plant biostimulants. Plant and Soil, 383, 3-41. https://doi.org/10.1007/ s11104-014-2131-8

Carmody, M., Waszczak, C., Idänheimo, N. and Saarinen, T. (2016). ROS signalling in a destabilised world: A molecular understanding of climate change. Journal of Plant Physiology, 203, 69-83. https://doi.org/10.1016/j.jplph.2016.06.008

Chen, K., Arora, R. and Arora, U. (2010). Osmopriming of spinach (Spinacia oleracea L. cv. Bloomsdale) seeds and germination performance under temperature and water stress. Seed Science and Technology, 38, 36-48. https://doi.org/10.15258/sst.2010.38.1.04

Chen, K. and Arora, R. (2013). Priming memory involves seed stress-tolerance. Environmental and Experimental Botany, 94, 33-45. https://doi.org/10.1016/j.envexpbot. 2012.03.005 
Chitwood, J., Shi, A., Evans, M., Rom, C., Gbur Junior, E. E., Motes, D., Chen, P. and Hensley, D. (2016). Effect of temperature on seed germination in spinach (Spinacia oleracea). HortScience, 51, 1475-1478. https://doi.org/10.21273/HORTSCI11414-16

Craigie, J. S. (2011). Seaweed extract stimuli in plant science and agriculture. Journal Applied Phycology, 23, 371-393. https://doi. org/10.1007/s10811-010-9560-4

Das, K. and Roychoudhury, A. (2014). Reactive oxygen species (ROS) and response of antioxidants as ROS-scavengers during environmental stress in plants. Frontiers in Environmental Science, 2, 53. https://doi.org/10.3389/fenvs.2014.00053

El-Sheekh, M. M. and El-Saied, A. el-D. (2000). Effect of crude seaweed extracts on seed germination, seedling growth and some metabolic processes of Vicia faba L. Cytobios, 101, 23-35.

Guinan, K. J., Sujeeth, N., Copeland, R. B., Jones, P. W., O’Brien, N. M., Sharma, H. S. S., Prouteau, P. F. J. and O'Sullivan, J. T. (2013). Discrete roles for extracts of Ascophyllum nodosum in enhancing plant growth and tolerance to abiotic and biotic stresses. Acta Horticulturae, 1009, 127-135. https://doi.org/10.17660/ActaHortic.2013.1009.15

Heath, R. L. and Packer, L. (1968). Photoperoxidation in isolated chloroplasts: I. Kinetics and stoichiometry of fatty acid peroxidation. Arch Biochem Biophys, 125, 180-198. https://doi.org/10.1016/0003-9861(68)90654-1

Hernández-Herrera, R. M., Santacruz-Ruvalcaba, F., Ruiz-López, M. A., Norrie, J. and Hernández-Carmona, G. (2014). Effect of liquid seaweed extracts on growth of tomato seedlings (Solanum lycopersicum L.). Journal Applied Phycology, 26, 619-628. https://doi. org/10.1007/s10811-013-0078-4

Jisha, K. C., Vijayakumari, K. and Puthur, J. T. (2013). Seed priming for abiotic stress tolerance: an overview. Acta Physiologiae Plantarum, 35, 1381-1396. https://doi.org/10.1007/s11738-012-1186-5

Joosen, R. V. L., Kodde, J., Willems, L. A. J., Ligterink, W., van der Plas, L. H. W. and Hilhorst, H. W. M. (2010). Germinator: a software package for high-throughput scoring and curve fitting of Arabidopsis seed germination. The Plant Journal, 62, 148-159. https://doi. org/10.1111/j.1365-313X.2009.04116.x

Kavipriya, R., Dhanalakshmi, P. K., Jayashree, S. and Thangaraju, N. (2011). Seaweed extract as a bioestimulant for legume crop, green gram. Journal Ecobiotechnology, 3, 16-19.

Lira, J. M. S., Lara, T. S., Rodrigues, A. C., Dousseau, A., Magalhães, M. M. and Alvarenga, A. A. (2015). Cross-tolerance mechanism induction in melon seeds by priming prior drying. Ciência e Agrotecnologia, 39, 131-137. https://doi.org/10.1590/S1413-70542015000200004

Maguire, J. D. (1962). Speeds of germination-aid selection and evaluation for seedling emergence and vigor. Crop Science, 2, $176-177$. https://doi.org/10.2135/cropsci1962.0011183X000200020033x

Masondo, N. A., Kulkarni, M. G., Finnie, J. F. and Van Staden, J. (2018). Influence of biostimulants-seed-priming on Ceratotheca triloba germination and seedling growth under low temperatures, low osmotic potential and salinity stress. Ecotoxicology and Environmental Safety, 147, 43-48. https://doi.org/10.1016/j.ecoenv.2017.08.017

Mittler, R. and Zilinskas, B. A. (1994). Regulation of pea cytosolic ascorbate peroxidase and other antioxidant enzymes during the progression of drought stress and following recovery from drought. The Plant Journal, 5, 397-405. https://doi.org/10.1111/j.1365-313x.1994.00397.x

Möller, M. and Smith, M. L. (1998). The applicability of seaweed suspension as priming treatments of lettuce (Lactuca sativa L.) seeds. Seed Science and Technology, 26, 425-438.

Murili, C. N., Bhanuprakash, K. and Channakeshava, B. C. (2016). Impact of seed priming on vigour in onion (Allium cepa L.). Journal of Applied Horticulture, 18, 68-70. https://doi.org/10.37855/jah.2016.v18i01.15

Nahar, K., Hasanuzzaman, M., Alam, M. M. and Fujita, M. (2014). Exogenous glutathione confers high temperature stress tolerance in mung bean (Vigna radiata L.) by modulating antioxidant defense and methylglyoxal detoxification system. Environmental and Experimental Botany, 112, 44-54. https://doi.org/10.1016/j.envexpbot.2014.12.001 
Nakagawa, J. (1994). Testes de vigor baseados na avaliação de plântulas. In R. D. Vieira and N. M. Carvalho (Eds.), Testes de vigor em sementes (p. 49-85). Jaboticabal: FUNEP.

Nascimento, W. M. (2004). Condicionamento Osmótico de Sementes de Hortaliças [Circular Técnica 33]. Brasília: Embrapa. [Accessed Feb. 15, 2020]. Available at: https://www.infoteca.cnptia.embrapa.br/bitstream/doc/778185/1/ct33.pdf

Paparella, S., Araújo, S. S., Rossi, G., Wijayasinghe, M., Carbonera, D. and Balestrazzi, A. (2015). Seed priming: state of the art and new perspectives. Plant Cell Reports, 34, 1281-1293. https://doi.org/10.1007/s00299-015-1784-y

R Core Team. (2020). R: A language and environment for statistical computing. Vienna: R Foundation for Statistical Computing. [Accessed Aug. 19, 2020]. Available at: http://www.r-project.org/index.html

Sako, Y., McDonald, M. B., Fujimura, K., Evans, A. F. and Bennett, M. A. (2001). A system for automated seed vigor assessment. Seed Science and Technology, 29, 625-636.

Sarhan, T. Z., Mohammed, G. H. and Teli, J. A. (2011). Effect of bio and organic fertilizers on growth, yield and fruit quality of summer squash. Sarhad Journal of Agriculture, 27, 377-383.

Sharma, S. H. S., Lyons, G., McRoberts, C., McCall, D., Carmichael, E., Andrews, F., Swan, R., McCormack, R. and Mellon, R. (2012). Biostimulant activity of brown seaweed species from Strangford Lough: compositional analyses of polysaccharides and bioassay of extracts using mung bean (Vigno mungo L.) and pak choi (Brassica rapa chinensis L.). Journal of Applied Phycology, 24, $1081-1091$. https://doi.org/10.1007/s10811-011-9737-5

Taiz, L., Zeiger, E., Møller, I. M. and Murphy, A. (2017). Estresse Abiótico. In Fisiologia e Desenvolvimento Vegetal (p. 731-759). Porto Alegre: Artmed.

Turan, M. and Köse, C. (2004). Seaweed extracts improve copper uptake of grapevine. Acta Agriculturae Scandinavica, Section B-Soil \& Plant Science, 54, 213-220. https://doi.org/10.1080/09064710410030311

Verkleij, F. N. (1992). Seaweed extracts in agriculture and horticulture: a review. Biological Agriculture \& Horticulture, 8, 309-324. https:// doi.org/10.1080/01448765.1992.9754608

Wahid, A., Gelani, S., Ashraf, M. and Foolad, M. R. (2007). Heat tolerance in plants: an overview. Environmental and Experimental Botany, 61, 199-223. https://doi.org/10.1016/j.envexpbot.2007.05.011

Wojtyla, Ł., Lechowska, K., Kubala, S. and Garnczarska, M. (2016). Molecular processes induced in primed seeds increasing the potential to stabilize crop yields under drought conditions. Journal of Plant Physiology, 203, 116-126. https://doi.org/10.1016/j.jplph.2016.04.008

Yan, M. (2016). Hydro-priming increases seed germination and early seedling growth in two cultivars of Napa cabbage (Brassica rapa subsp. pekinensis) grown under salt stress. The Journal of Horticultural Science and Biotechnology, 91, 421-426. https://doi.org/10.10 $80 / 14620316.2016 .1162031$

Ziaf, K., Ahmad, M. F., Amjad, M., Jahangir, M. M. and lqbal, Q. (2017). Pericarp loosening and reduced lipid peroxidation enhances spinach seed performance and biomass production under normal and saline conditions. Pakistan Journal of Agricultural Sciences, 54 , 299-309. https://doi.org/10.21162/PAKJAS/17.3711

In the article Seed priming with seaweed extract mitigate heat stress in spinach: effect on germination, seedling growth and antioxidant capacity with DOI: https://doi.org/10.1590/1678-4499.20200127, published in Bragantia vol.79 no.4 Campinas Oct./Dec. 2020:

In the footline where is read Bragantia, Campinas, v. 79, n. 4, p.377-386, 2020 should be read Bragantia, Campinas, v. 79, n. 4, p.502-511, 2020. 